\title{
DETEKSI BAHAN KIMIA PADA DAGING IKAN KONSUMSI MENGGUNAKAN METODE NEURAL NETWORK BERDASARKAN ANALISIS TEKSTUR DAN WARNA
}

\author{
Salman Suleman ${ }^{1)}$, Roys Pakaya ${ }^{2)}$ \\ ${ }^{1,2}$ Program Studi Teknik Informatika, Politeknik Gorontalo \\ Email: salman@ poligon.ac.id ${ }^{1)}$
}

\begin{abstract}
ABSTRAK
Ikan merupakan salah satu sumber protein bagi tubuh dan memiliki kandungan gizi yang sangat bermanfaat bagi kesehatan. Selain protein yang tinggi, ikan juga mengandung asam lemak omega 3 yang dibutuhkan untuk pertumbuhan otak, serta kalsium, vitamin D, dan fosfor yang dibutuhkan anak untuk pertumbuhan tulang. Menurut data dari Kementerian Kelautan dan Perikanan, penduduk Indonesia di wilayah bagian timur tergolong tinggi dalam hal mengkonsumsi ikan, terutama penduduk di Gorontalo konsumsi ikan sebanyak $40 \mathrm{~kg}$ per kapita per tahun, berbeda dengan penduduk yang ada di pulau Jawa, Sumatera dan Kalimantan yang hanya mengkonsumsi ikan antara 32-43 per kapita per tahun (DKPP, 2013). Sehingga ikan yang sudah tidak layak konsumsi, diolah dengan mencampur bahan-bahan yang sangat berbahaya agar awet dan tampilannya tampak segar. Zat kimia yang paling sering digunakan adalah formalin, boraks dan pewarna tekstil. Jika zat kimia ini masuk dalam tubuh, dampak negatif yang bisa terjadi adalah dapat memicu aneka kanker, kelainan genetik, cacat bawaan ketika lahir, keracunan, kelemahan saraf.

Dalam mengetahui bahan kimia pada ikan, khusunya pada daging ikan konsumsi dapat diamati secara langsung, dimulai dengan tahapan pembedahan pada ikan. Ikan akan dibedah menjadi dua bagian daging yaitu daging sisi kiri dan kanan. Namun untuk mengetahui bahan kimia pada ikan dengan menggunakan cara ini sering terjadi banyak kesalahan. Tahapan deteksi bahan kimia pada daging ikan konsumsi terdiri dari tiga permasalahan utama yaitu pengambilan gambar daging ikan, ekstraksi fitur pada tekstur dan warna daging ikan serta proses klasifikasi. Pada tahap pengambilan gambar masih dilakukan dengan secara manual yaitu dengan meletakkan ikan yang sudah dibedah pada wadah kemudian diambil gambarnya dengan menggunakan kamera smartphone atau kamera lainnya.

Pada tahapan ekstraksi tekstur penulis menggunakan metode Gray Level Co-Occurrence Matrix $(G L C M)$ selanjutnya pada tahapan ekstraksi warna menggunakan metode ruang warna Red, Green, Blue (RGB). Pada proses klasifikasi menggunakan metode Neural Network (NN)
\end{abstract}

Kata kunci: deteksi, kimia, daging, konsumsi

\section{ABSTRACT}

Fish is one source of protein for the body and has a nutritional content that is very beneficial for health. In addition to being high in protein, fish also contain omega-3 fatty acids needed for brain growth, as well as calcium, vitamin D, and phosphorus that children need for bone growth. According to data from the Ministry of Maritime Affairs and Fisheries, the population of Indonesia in the eastern part of the region is classified as high in terms of fish consumption, especially residents in Gorontalo whose fish consumption is as much as $40 \mathrm{~kg}$ per capita per year, in contrast to populations in Java, Sumatra and Kalimantan which only consume fish between 32-43 per capita per year. The high demand for fish is the target of rogue traders to cheat. Fish that are no longer fit for consumption, are damaged and even have wavy are processed by mixing ingredients that are very dangerous so that they last longer and look fresh. The most commonly used chemicals are formalin, borax and textile dyes. If these chemicals enter the body, the negative impact that can occur is that it can trigger various cancers, genetic disorders, congenital defects at birth, poisoning, nerve weakness.

In knowing the chemicals in fish, especially fish consumption can be observed directly, starting with the stages of surgery on fish. The fish will be dissected into two pieces of meat namely left and right side meat. But to find out the chemicals in fish using this method often many errors occur. The stages of chemical detection in fish consist of three main problems namely image capture, feature extraction and classification. At the stage of shooting is still done manually, namely by putting the fish that has been dissected in a container then taken pictures using a smartphone camera or other camera.

At the texture extraction stage the author uses the next GLCM method at the color extraction stage using the RGB method. In the classification process using the Neural Network method. As for the target outputs in this study are accredited national journals and the Technological Readiness Level (TKT) scale 1. Keywords: detection, chemistry, meat, consumption 


\section{Latar Belakang}

Indonesia merupakan negera maritim terbesar di dunia. Sebagian besar wilayah Indonesia merupakan kawasan perairan. Kondisi ini sangat memungkinkan tumbuh dan berkembangnya beragam jenis biota air laut maupun air tawar. Ikan merupakan salah satu biota air yang banyak terdapat di perairan indonesia. Diperkirakan sekitar 8500 spesies ikan yang hidup di wilayah perairan Indonesia (Australia Museum) atau merupakan 45 persen dari jumlah spesies yang ada di dunia. Sebanyak 1300 spesies dari jumlah tersebut menempati perairan air tawar (Kottelat \& Whitten, 1996).

Sektor perikanan dan kelautan merupakan ujung tombak pembangunan perekonomian di Gorontalo. Gorontalo memiliki hasil perikanan dan kelautan yang sangat melimpah. Dalam kurun waktu tahun 2011-2017, produksi perikanan di Gorontalo mengalami kenaikan sebesar 8,38 persen tiap tahunnya dengan rata-rata kenaikan produksi sebesar 92.494 ton. Budidaya perikanan darat merupakan penghasil ikan terbesar dengan produksi 115.477,39 ton, atau sebesar 54,36 persen dari keseluruhan produksi sebesar 212.427,50 ton, sedangkan hasl perikanan laut mencapai 95.991 ton atau sebesar 45,64 persen (DKP, 2013).

Dalam mengetahui bahan kimia pada ikan, khusunya pada daging ikan konsumsi dapat diamati secara langsung, dimulai dengan tahapan pembedahan pada ikan. Ikan akan dibedah menjadi dua bagian daging yaitu daging sisi kiri dan kanan. Namun untuk mengetahui bahan kimia pada ikan dengan menggunakan cara ini sering terjadi banyak kesalahan.

Penelitian mengenai klasifikasi daging dengan menggunakan ekstraksi fitur tekstur sudah pernah dilakukan pada penelitian yang berjudul "Recognition Kualitas Daging Ikan Tuna dengan Metode Learning Vektor Quantization (LVQ) Berdasarkan Fitur Ekstraksi Tekstur dan Warna" (Pakaya R dan Suleman S, 2018). Pada penelitian tersebut didapatkan akurasi tertinggi yaitu $88.66 \%$ dengan menggunakan ekstraksi fitur tekstur dan menggunakan metode klasifikasi Learning Vektor Quantization (LVQ).

Pada sektor pertanian ekstraksi ciri berdasarkan warna dan tekstur digunakan untuk klasifikasi juga telah dilakukan oleh Huang menggunakan Gray Level Co-occurance Matrix untuk ekstraksi ciri tekstur dan nilai mean $R G B$ sebagai ciri warna pada bibit Phalaenopsis yang terinfeksi dengan hasil 89.6\% (K.Y. Huang,,2007)

Berdasarkan referensi penelitian yang telah disebutkan di atas bahwa penggunaan metode gray level co-occurance matix (GLCM) untuk ekstraksi ciri tekstur dan nilai mean RGB serta Learning Vektor Quantization (LVQ) sebagai klasifikasi menghasilkan akurasi yang cukup tinggi. Pada penelitian ini penulis menggunakan metode klasifikasi lain yaitu Neural Network (NN) dengan menggunakan metode gray level co-occurance matix (GLCM) untuk ekstraksi fitur dan mean $R G B$ sebagai ekstraksi warna.

Ruang warna $R G B$ biasa diterapkan pada monitor CRT dan kebanyakan system grafika computer. Ruang warna ini menggunakan tiga komponen dasa yaitu merah (R), hijau (G), dab biru (B). Setiap piksel dibentuk oleh ketiga komponen tersebut. $R G B$ biasa digunakan karena kemudahan dalam perancangan hardware, tetapi tidak ideal untuk beberapa aplikasi. Mengingat warna merah, hijau, dan biru sesungguhnya berkolerasi erat, sangat sulit untuk beberapa algoritma pemrosesan citra (crane, 1997).

Metode Gray Level Co-occurance Matix $(G L C M)$ menggunakan perhitungan tekstur pada orde kedua. Pengukuran tekstur pada orde pertama menggunakan perhitungan static didasarkan pada nilai piksel citra asli semata, seperti varians, dan tidak memperhatikan hubungan ketetangan piksel. Pada orde kedua, hubungan antarpasangan dua piksel citra asli diperhitungkan (Hall-Beyer, 2007).

Klasifikasi daging ikan konsumsi dilakukan dengan memanfaatkan metode Neural Network (NN). Proses pengolahan nila berdasarkan nilai asli ekstraksi ciri kemudian di klasifikasi sehingga mendapatkan hasil.

\section{METODOLOGI PENELITIAN \\ 2.1. Lokasi Penelitian}

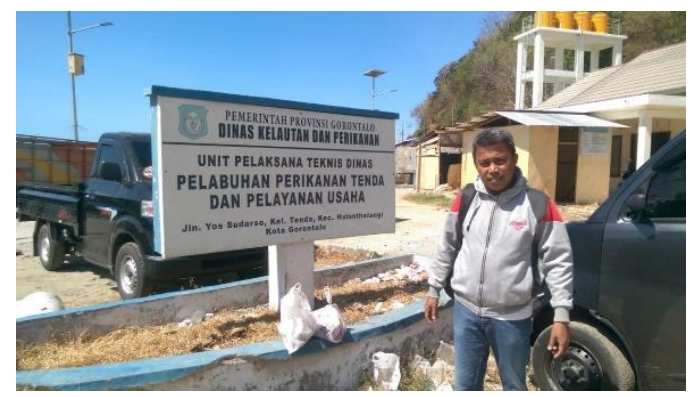

Gambar 1. Tempat pelelangan ikan Gorontalo

Lokasi penelitian dilakukan di Tempat Pelelangan Ikan Kota Gorontalo (TPI) yang menjadi pusat penjualan ikan yang berada di wilayah kota Gorontalo. 


\subsection{Rancangan Tahapan Penelitian}

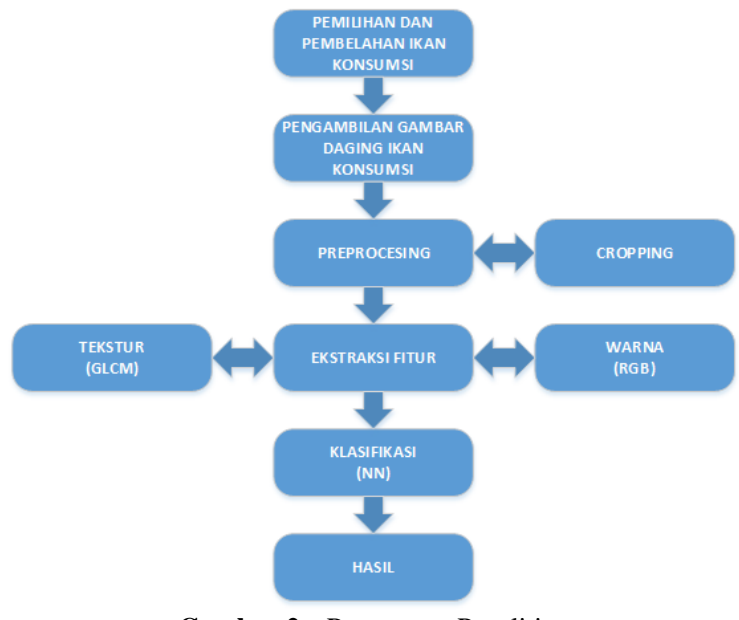

Gambar 2. Rancangan Penelitian

2.2.1 Tahapan dalam pemilihan dan pembelahan ikan konsumsi yaitu:

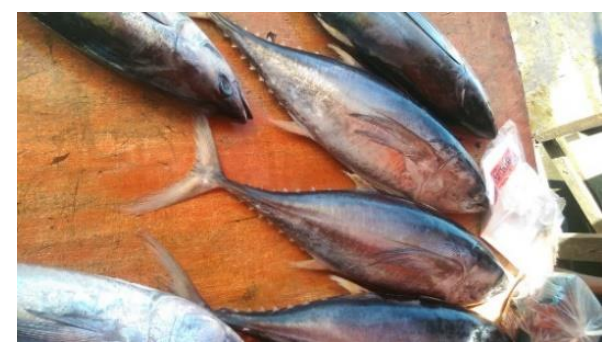

Gambar 3. Pemilihan ikan konsumsi

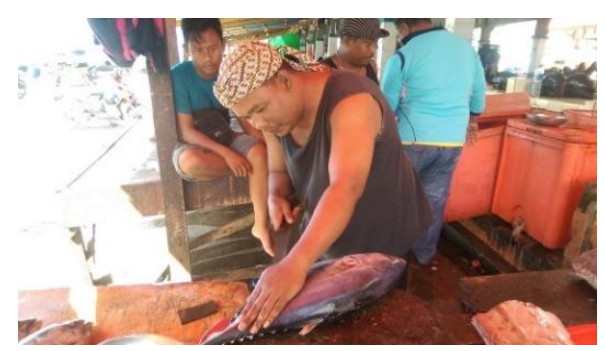

Gambar 4. Pembelahan ikan konsumsi

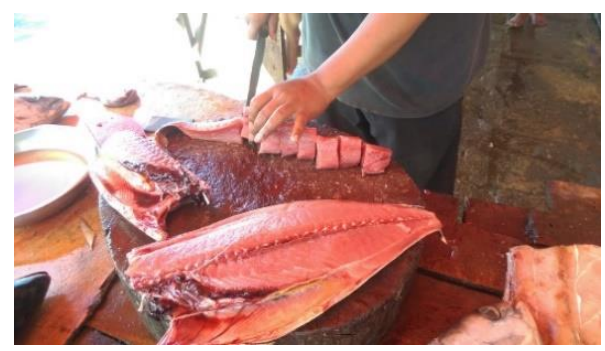

Gambar 5. Daging hasil pembelahan ikan

Kegiatan ini diawali dengan pemilihan daging ikan konsumsi, lalu potong kepala ikan konsumsi. Posisikan pisau di belakang sirip dada ikan, potong diagonal kebawah, lakukan di kedua sisi ikan. Filet tubuh ikan kemudian potong menjadi beberapa bagian daging ikan. Langkah terakhir bersihkan daging ikan konsumsi dengan air bersih.

\subsubsection{Pengambilan gambar daging ikan konsumsi}

Jenis ikan yang akan di jadikan objek peneltian yaitu ikan yellowfin tuna. Penelitian ini menggunakan gambar daging ikan konsumsi dengan jumlah 100 gambar daging ikan konsumsi. Selanjutnya 100 gambar daging ikan konsumsi tersebut dibagi menjadi dua bagian yaitu 50 gambar daging ikan konsumsi untuk klasifikasi daging ikan konsumsi yang masih original (asli) dan 50 gambar daging ikan konsumsi untuk klasifikasi daging ikan yang sudah di campur dengan bahan kimia. 30 gambar daging ikan konsumsi dari masing-masing klasifikasi digunakan sebagai data latih dan 20 gambar daging ikan konsumsi dari masing-masing klasifikasi digunakan sebagai data uji.

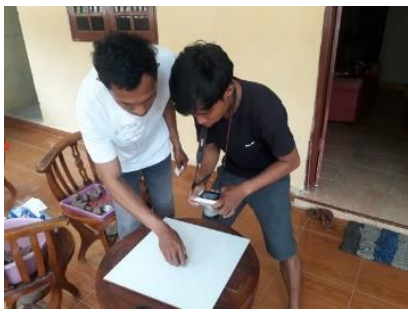

Gambar 6. Pengambilan gambar

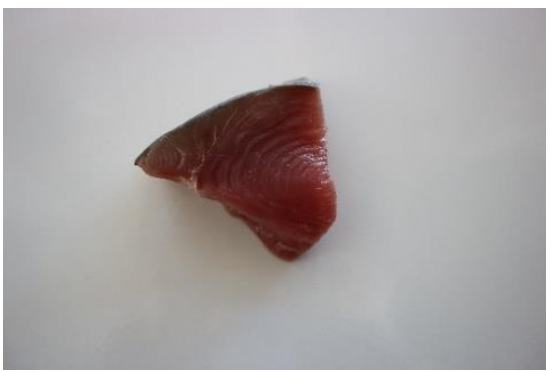

Gambar 7. Hasil pengambilan gambar

Proses pengambilan gambar di luar rungan dilakukan pada pagi hari dari pukul $09.00-10.00$ Wita saat cuaca matahari cerah sedangkan pengambilan gambar di malam hari atau di dalam ruangan sebaiknya menggunakan bantuan tubular lamp (TL), karena cahaya dari lampu $T L$ tidak akan mengubah tampilan ikan dari segi tekstur dan warna. Gambar daging ikan diambil harus pada jarak antara $15 \mathrm{~cm}$ dan $20 \mathrm{~cm}$ dengan sudut kemiringan $130^{\circ}$ dengan syarat tidak boleh menggunakan bantuan cahaya (blitz). Pengambilan Hasil pengambilan gambar berupa gambar warna $(R G B)$ dengan resolusi 100 x 100 pixel citra asli. Gambar 7 merupakan hasil pengambilan gambar yang baik dan benar. 


\subsubsection{Preprocessing}

Cropping merupakan proses untuk menghilangkan bagian-bagian yang dianggap tidak penting pada gambar. Keuntungan cropping:

- Data lebih siap diolah

- Data sesuai dengan kebutuhan, misalnya pada proses binerisasi dan bipolarisasi

- Fitur data lebih jelas

- Menghilangkan noise

Kerugian cropping:

- Perlu tambahan waktu komputasi sehingga pengolahan data secara keseluruhan lebih lama

- Algoritma cropping kadang-kadang menghilangkan informasi dari gambar.

Persamaan yang digunakan pada tahapan cropping adalah sebagai berikut:

$\mathrm{w} '=\mathrm{xR}-\mathrm{xL}$

$\mathrm{h}^{\prime}=\mathrm{yB}-\mathrm{yT}$

dimana:

w' = ukuran width (lebar) citra yang baru

h' = ukuran height (tinggi) citra yang baru

$(\mathrm{xL}, \mathrm{yT})=$ koordinat titik pojok kiri atas citra yang dicropping

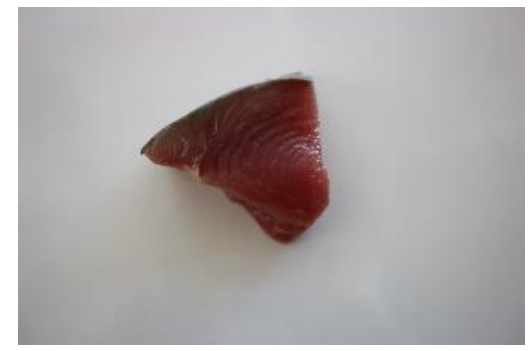

Citra asli

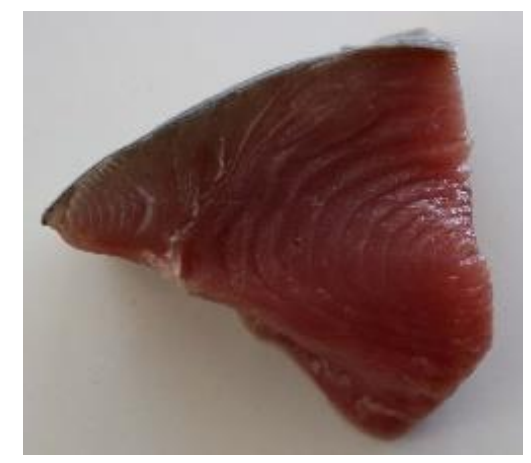

Hasil cropping

Gambar 8. Hasil cropping

3. HASIL DAN PEMBAHASAN

3.1 Feature ektraksi teksture dengan GLCM

Pada tahap ini di lakukan Ekstraksi ciri berbasis analisis tekstur. Metode GLCM menghasilkan 5 (lima) ekstraksi ciri dari suatu citra digital tiap sudut ketetangaan pikselnya antara lain:

1. Angular Second Moment (ASM) merupakan ukuran hegemonitas citra

2. Kontras merupakan ukuran keberadaan haras keabuan dalam citra

3. Inverse Different Moment (IDM) digunakan untuk mengukur hegemonitas

4. Entropi adalah ukuran ketidakteraturan aras keabuan dalam citra

5. Korelasi adalah ukuran ketergantungan linier antar nilai aras keabuan dalam citra.

Tabel 2.1 Formula Extraksi ciri

\begin{tabular}{|l|l|l|}
\hline $\begin{array}{l}\mathbf{N} \\
\mathbf{o}\end{array}$ & Feature & Formula \\
\hline 1. & Contras & $\sum i \sum j(i-j)^{2} C(i, j)$ \\
\hline 2. & Energi & $\sum i \sum j C^{2}(i, j)$ \\
\hline 3. & Entropy & $\sum i \sum j \mathrm{C}(i, j) \log (\mathrm{C}(i, j)$ \\
\hline 4. & $\begin{array}{l}\text { Homogen } \\
\text { itas }\end{array}$ & $\sum i \sum j \frac{C(i, j)}{1+|i+j|}$ \\
\hline
\end{tabular}

Sumber : (Lee \& Choi 2010)

Untuk sudut yang dibentuk dari nilai piksel citra menggunakan GLCM adalah $0^{0}, 45^{0}, 90^{\circ}, 135^{\circ}$ (Eleyan \& Demirel 2011),

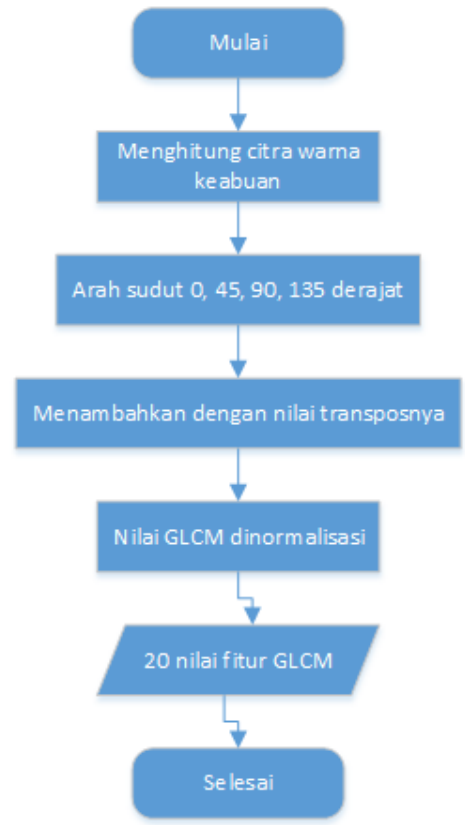

Gambar 9. Alur dari GLCM

Untuk kepentingan ilustrasi, ketetangaan piksel dapat dipilih ke arah kanan. Salah satu cara 
untuk mempresentasikan hubungan ini yaitu berupa $(1,0)$, yang menyatakan hubungan dua piksel yang sejajar horizontal dengan piksel yang bernilai 1 diikuti dengan piksel bernilai 0 , berdasarkan komposisi tersebut, jumlah kelompok piksel yang memenuhi hubungan tersebut dihitung. Hal ini diilustrasikan di Gambar 10.

\begin{tabular}{|l|l|l|l|}
\hline 0 & 0 & 1 & 1 \\
\hline 0 & 0 & 1 & 1 \\
\hline 0 & 2 & 2 & 2 \\
\hline 2 & 2 & 3 & 3
\end{tabular}$\quad \quad$\begin{tabular}{|l|l|l|l|}
2 & 2 & 1 & 0 \\
\hline 0 & 2 & 0 & 0 \\
\hline 9 & 0 & 3 & 1 \\
\hline 0 & 0 & 0 & 1 \\
\hline
\end{tabular}

(a) Citra Asli (b) Jumlah Pasangan Piksel Gambar 10. Penentuan awal matriks GLCM berbasis pasangan dua piksel

Matriks di gambar 9(b) dinamakan matrix framework. Matriks ini perlu diolah menjadi matriks simetris dengan cara menambahkan dengan hasill transposnya, sebagaimana diperlihatkan di Gambar 11.

$$
\begin{aligned}
& {\left[\begin{array}{llll}
2 & 2 & 1 & 0 \\
0 & 2 & 0 & 0
\end{array}\right]\left[\begin{array}{llll}
2 & 0 & 0 & 0 \\
2 & 2 & 0 & 0
\end{array}\right]\left[\begin{array}{llll}
4 & 2 & 1 & 0 \\
2 & 4 & 0 & 0
\end{array}\right]} \\
& \left.\begin{array}{llll}
0 & 0 & 3 & 1
\end{array}\right]+\left[\begin{array}{llll}
2 & 2 & 0 & 0 \\
1 & 0 & 3 & 0 \\
0 & 0 & 1 & 1
\end{array}=\left[\begin{array}{llll}
2 & 4 & 0 & 0 \\
1 & 0 & 6 & 1
\end{array}\right.\right. \\
& {\left[\begin{array}{llll}
0 & 0 & 3 & 1 \\
0 & 0 & 0 & 1
\end{array}\right]^{+}\left(\begin{array}{llll}
1 & 0 & 3 & 0 \\
0 & 0 & 1 & 1
\end{array}\right]=\left[\begin{array}{llll}
1 & 0 & 6 & 1 \\
0 & 0 & 1 & 2
\end{array}\right)}
\end{aligned}
$$

Gambar 11. Contoh pembentukan matriks GLCM yang simetris

Tabel di bawah ini memperlihatkan contoh hasil ekstraksi fitur menggunakan metode GLCM pada daging ikan konsumsi dengan bantuan aplikasi Matlab sebagai tool dalam pengolahan data.

Tabel 3.1 Hasil ekstraksi teksture menggunakan GLCM

\begin{tabular}{|l|l|lr|}
\hline \multicolumn{1}{|c|}{ Klasifikasi } & \multicolumn{2}{|c|}{ Daging } & \multicolumn{2}{|c|}{ Ciri } \\
\hline Tidak mengandung bahan \\
kimia
\end{tabular}

Dari table di atas dapat di lihat bahwa daging yang mengandung bahan kimia nilai ciri entropi lebih besar dibandingkan dengan daging yang tidak mengandung bahan kimia. Hal ini memberikan informasi bahwa semakin besar nilai entropi maka tekstur daging semakin tidak beraturan.

\subsection{Feature ektraksi warna dengan RGB}

Ruang warna RGB biasa diterapkan pada monitor CRT dan kebanyakan sistem grafika komputer. Ruang warna ini terdiri dariruang merah (R), hijau (G), dan biru (B). Setiap piksel dibentuk oleh ketiga komponen tersebut. Fitur warna dapat diperoleh melalui perhitungan statistis seperti rerata, deviasi standar, skewness, dan kurtosis. Perhitungan dikenakan pada setiap komponen R, G. dan B.

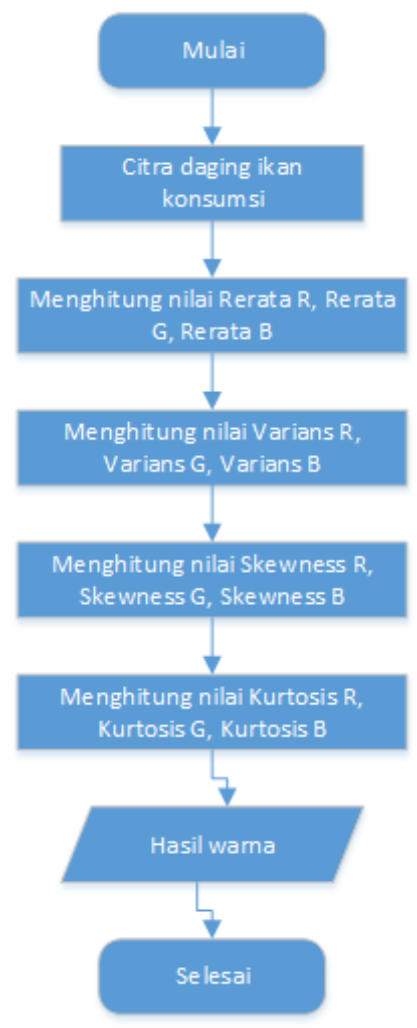

Gambar 12. Alur warna RGB

Rerata memberikan nilai mengenai distribusi dan dengan persamaan rumus:

$$
\mu=\frac{1}{M N} \sum_{i=1}^{M} \sum_{j=1}^{N} P_{i j}
$$

Varians menyatakan luas penyebaran distribusi. Adapun persamaan yang digunakan adalah 


$$
\sigma=\sqrt{\frac{1}{M N} \sum_{i=1}^{M} \sum_{j=1}^{N}\left(P_{i j}-\mu\right)^{2}}
$$

Skewness atau kecondongan merupakan ukuran ketidaksimetrisan. Skewness dihitung dengan persamaan seperti berikut:

$$
\theta=\frac{\sum_{i=1}^{M} \sum_{j=1}^{N}\left(P_{i j}-\mu\right)^{3}}{M N \sigma^{3}}
$$

Kurtosis adalah nilai yang menyatakan penyebaran data bersifat meruncing. Persamaya seperti berikut:

$$
\gamma=\frac{\sum_{i=1}^{M} \sum_{j=1}^{N}\left(P_{i j}-\mu\right)^{4}}{M N \sigma^{4}}-3
$$

\subsection{Hasil Klasifikasi Neural Network}

Neural network merupakan salah satu bagian yang berbasis competitive learning atau winner take all, di mana dari nilai keluaran yang diberikan neuron dalam suatu layer keluaran hanyalah neuron yang mempunyai nilai terkecil saja atau disebut juga neuron penenang yang diperhatikan.

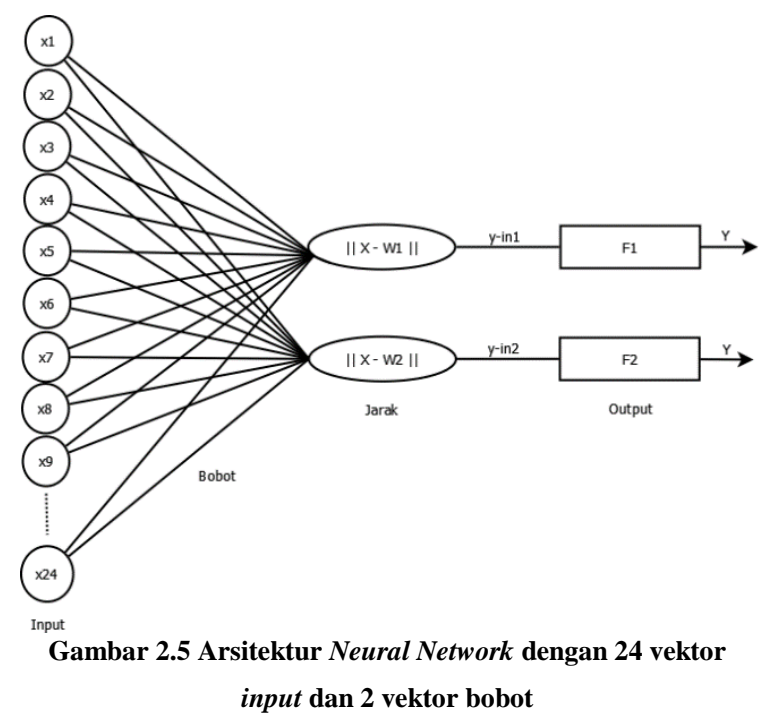

Penelitian ini menggunakan citra daging ikan konsumsi dengan jumlah 100 citra daging ikan komsumsi yang semuanya diambil langsung dari

\begin{tabular}{|c|c|c|c|}
\hline Klasinkasi & Daging & & \\
\hline $\begin{array}{l}\text { Tidak mengandung bahan } \\
\text { kimia }\end{array}$ & & $\begin{array}{l}\text { Rerata R } \\
\text { Rerata G } \\
\text { Rerata B } \\
\text { Varians R } \\
\text { Varians G } \\
\text { Varians B } \\
\text { Skw R } \\
\text { Skw G } \\
\text { Skw B } \\
\text { Kurt R } \\
\text { Kurt G } \\
\text { Kurt B }\end{array}$ & $\begin{array}{r}134,7643 \\
109,62 \\
105,7895 \\
47,94341 \\
69,36941 \\
71,16181 \\
0,088886 \\
0,051877 \\
0,133336 \\
-1,50389 \\
-1,65356 \\
-1,61699\end{array}$ \\
\hline Mengandung bahan kimia & & $\begin{array}{l}\text { Rerata R } \\
\text { Rerata G } \\
\text { Rerata B } \\
\text { Varians R } \\
\text { Varians G } \\
\text { Varians B } \\
\text { Skw R } \\
\text { Skw G } \\
\text { Skw B } \\
\text { Kurt R } \\
\text { Kurt G } \\
\text { Kurt B }\end{array}$ & $\begin{array}{r}117,590817 \\
96,27448433 \\
89,64496011 \\
47,06842143 \\
63,90491451 \\
67,8547259 \\
0,470080573 \\
0,418564268 \\
0,473658837 \\
-1,191385323 \\
-1,356615202 \\
-1,37574355\end{array}$ \\
\hline
\end{tabular}
tempat pelelangan ikan (TPI) di Gorontalo.
Tabel 3.2 Hasil ekstraksi warna menggunakan RGB

Dari table di atas dapat di lihat bahwa daging yang mengandung bahan kimia mempunyai selisih nilai yang besar antara ciri rerata $R$, rerata $G$, rerata B. Sedangkan pada daging yang tidak mengandung bahan kimia memiliki selisih nilai kecil pada masingmasing ciri rerata $R$, rerata $G$, rerata. Hal ini memberikan informasi bahwa daging yang tidak mengandung bahan kimia mempunyai distribusi atau penyebaran warna yang merata pada semua ciri.

Selanjutnya 100 citra daging ikan konsumsi tersebut dibagi menjadi dua bagian yaitu 50 citra daging ikan konsumsi untuk klasifikasi daging yang tidak mengandung bahan kimia dan 50 citra daging ikan konsumsi untuk klasifikasi daging yang mengandung bahan kimia. Kemudian 30 citra daging ikan konsumsi dari masing-masing klasifikasi digunakan sebagai data latih dan 20 citra daging ikan konsumsi dari masing-masing klasifikasi digunakan sebagai data uji. bawah ini.

Hasil pengujian akan disajikan pada table di

\subsection{Hasil klasifikasi Neural Network}

Dari hasil testing diperoleh variasi terbaik deteksi bahan kimia pada daging ikan konsumsi dengan metode Neural Network sebesar 97,5\%. Hasil

\begin{tabular}{|c|c|c|c|c|c|c|c|c|c|}
\hline \multirow{3}{*}{ No } & \multirow{3}{*}{$\begin{array}{c}\text { Learning } \\
\text { rate }\end{array}$} & \multirow{3}{*}{$\begin{array}{c}\text { Hidden } \\
\text { Layer }\end{array}$} & \multirow{3}{*}{ Epoch } & \multicolumn{6}{|c|}{ Hasil } \\
\hline & & & & \multirow[t]{2}{*}{ MSE } & \multicolumn{2}{|c|}{$\begin{array}{c}\text { Citra latih } \\
\text { yang dikenali }\end{array}$} & \multicolumn{2}{|c|}{$\begin{array}{c}\text { Citra Uji yang } \\
\text { dikenali }\end{array}$} & \multirow[t]{2}{*}{$\begin{array}{c}\text { Akurasi } \\
\%\end{array}$} \\
\hline & & & & & 0 & l & 0 & 1 & \\
\hline 1. & 0,1 & 40 & 100 & 0,005 & 30 & 30 & 19 & 20 & $97,5 \%$ \\
\hline
\end{tabular}
pengujian akan disajikan pada table 3.3.

Tabel 3.3 Hasil pengujian dengan $N N$

\section{Keterangan :}

$0=$ Tidak mengandung bahan kimia

$1=$ Mengandung bahan kimia 


\subsection{Hasil citra latih 60}

$$
\begin{gathered}
\text { Accuracy }=\frac{\text { Total correct predictions }}{\text { Total correct and incorrect prediction }} \times 100 \\
=\frac{30+30}{30+0+0+30} \times 100 \\
\text { Accuracy }=\frac{60}{60} \times 100 \\
\text { Accuracy }=100 \%
\end{gathered}
$$

Tabel 3.4. Confusion matrix citra latih

\begin{tabular}{|c|c|c|c|}
\hline & & \multicolumn{2}{|c|}{ Actual } \\
\hline & & 0 & 1 \\
\hline \multirow{2}{*}{ Predicted } & 0 & 30 & 0 \\
\cline { 2 - 4 } & 1 & 0 & 30 \\
\hline
\end{tabular}

Keterangan :

$0=$ Tidak mengandung bahan kimia

$1=$ Mengandung bahan kimia

Pada confusion matrix untuk citra latih di atas:

1. Actual berjumlah 30 yang tidak mengandung bahan kimia, sistem mengklasifikasi ada 30 citra yang diklasifikasikan tidak mengandung bahan kimia.

2. Actual berjumlah 30 yang mengandung bahan kimia, sistem mengklasifikasi ada 30 citra yang diklasifikasikan mengandung bahan kimia.

Dari tabel confusion matrix di atas dapat dihitung Accuracy:

$$
\begin{gathered}
\text { Accuracy }=\frac{\text { Total correct predictions }}{\text { Total correct and incorrect prediction }} \times 100 \\
=\frac{30+30}{30+0+0+30} \times 100 \\
\text { Accuracy }=\frac{60}{60} \times 100 \\
\text { Accuracy }=100 \%
\end{gathered}
$$

\subsection{Hasil citra uji 40}

Tabel 3.5. Confusion matrix citra uji

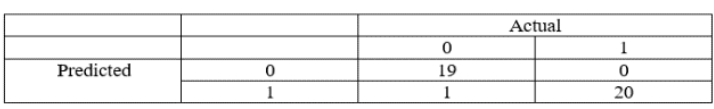

Keterangan :

$0=$ Tidak mengandung bahan kimia

1 = Mengandung bahan kimia

Pada confusion matrix untuk citra latih di atas:

1. Actual berjumlah 20 yang tidak mengandung bahan kimia, sistem mengklasifikasi ada 19 citra yang diklasifikasikan tidak mengandung bahan kimia dan 1 citra yang mengandung bahan kimia
2. Actual berjumlah 20 yang mengandung bahan kimia, sistem mengklasifikasi ada 20 citra yang diklasifikasikan mengandung bahan kimia.

Dari tabel confusion matrix di atas dapat dihitung Accuracy:

$$
\begin{gathered}
\text { Accuracy }=\frac{\text { Total correct predictions }}{\text { Total correct and incorrect prediction }} \times 100 \\
=\frac{19+20}{19+1+0+20} \times 100 \\
\text { Accuracy }=\frac{39}{40} \times 100 \\
\text { Accuracy }=97,5 \%
\end{gathered}
$$

\section{Kesimpulan dan Saran}

Dengan melakukan penelitian terhadap Deteksi Bahan Kimia Pada Daging Ikan Konsumsi Menggunakan Metode Neural Network Berdasarkan Analisis Tekstur Dan Warna dapat disimpulkan:

1. Metode Neural Network sangat baik untuk deteksi bahan kimia daging ikan konsumsi karena metode Neural Network mampu melakukan perhitungan secara parallel sehingga proses lebih singkat dan akurat.

2. Hasil Deteksi Bahan Kimia Pada Daging Ikan Konsumsi Menggunakan Metode Neural Network Berdasarkan Analisis Tekstur Dan Warna sebanyak 60 citra latih dan 40 citra uji, diperoleh akurasi 97,5\%.

Saran dari penelitian, Deteksi Bahan Kimia Pada Daging Ikan Konsumsi Menggunakan Metode Neural Network Berdasarkan Analisis Tekstur Dan Warna:

1. Proses pemilihan ikan sebagai sampel daging konsumsi dibuat sedetail mungkin, agar supaya hasil klasifikasi lebih baik

2. Untuk keberlanjutan penelitian dapat menggunakan metode supervices yang lain, untuk mendapat tingkat akurasi yang lebih baik.

\section{DAFTAR PUSTAKA}

Dinas Kelautan dan Perikanan Provinsi Gorontalo, 2013

Tuceryan dan Jain, “Texture Analysis. On Handbook of Pattern Recognition and Computer Viision" 1998

Kadir A dan Susanto A, "Teori dan Aplikasi Pengolahan Citra" 2012

Kottelat \& Whitten, "Freshwater fishes of Western Indonesia and Sulawesi: additions and corrections" 1996

Kulkarni, A. D., "Artificial Neural Networks for Image Understanding” 1994

Gonzalez dan Woods, "Digital Image Processing" 2002 
Martinez dan Martinez, “Computational Statistics Handbook With MATLAB” 2002

Pakaya R dan Suleman S, "Recognition Kualitas Daging Ikan Tuna Dengan Metode Learning Vector Quantization (Lvq) Berdasarkan Fitur Ekstraksi Tekstur Dan Warna" 2018

Xie dkk, "Quantitatively linking collagen alteration and epithelial tumor progression by second harmonic generation microscopy" 2010 